\title{
Island Tourism Brand Identities: A Review of Themes in Island Tourism Logos
}

\author{
Susan C. Graham (corresponding author) \\ Faculty of Business, University of Prince Edward Island \\ scgraham@upei.ca
}

\author{
Louise M. Campbell \\ Graduate Student, Master of Arts in Island Studies, University of \\ Prince Edward Island
}

Publication Information:

Received 2 April 2021, Accepted 13 May 2021, Available online 29 June 2021

DOI: 10.21463/jmic.2021.10.1.04

\begin{abstract}
All destinations-including islands-have an identity, shaped by the shared lived experiences and perspectives of various parties. Because sense of place is inherently reliant on human interaction (both with place and with each other), island identities are created, co-created, and communicated through various channels. One such channel is the messaging produced to market island destinations to various audiences. In marketing, a brand identity comprises the attributes or characteristics that separate one brand from another and highlight its uniqueness. Island destinations, like other tourism destinations (and brands in general), embed themes in their logos to help create a brand identity and to communicate with target audiences. The current study analyzed a sample of 84 island destination logos and identified a number of recurrent themes, with water, landscape/seascape, flora and fauna, and islandness being most prominent. Findings are discussed in the context of island identity, tourism, and marketing, highlighting opportunities for further exploration by island scholars and marketers alike. A greater understanding of island branding strategy is critical, as it offers island destinations a crucial advantage in an increasingly competitive tourism industry.
\end{abstract}

\section{Keywords}

brand identity, branding, island identity, island tourism, logo imagery, thematic analysis, tourism logos

\section{Introduction}

Islands. The very word evokes strong emotions and reactions, often steeped in history, mystique, and wonder. The earliest travellers sought safe harbour, sustenance, and opportunity along island shores, while many modern-day travellers seek an escape, a fantasy, an adventure, and a lifestyle associated with more piña coladas and fewer emails 
(Baldacchino, 2010; Grydehøj, 2011). The art world, including literature, visual arts, and music, is rife with depictions of the island as paradise, refuge, or enigma (Baldacchino, 2006; Van Duzer, 2006). Baldacchino (2010, p. 379) suggests that this rich tapestry of island representation, whether based on real or imagined allusions, constitutes the earliest form of island branding, asserting that "islands have been branded long before the concept found its way into management schools and contemporary marketing discourse."

All destinations, including islands, have an identity (or identities), shaped by the shared lived experiences and perspectives of various parties. Identity is, quite simply, what makes a place unique. Typically associated with humans rather than objects or places, identity reflects the self, both as perceived internally and observed externally (Nimführ and Meloni, 2021). When applied to places, identity refers to the ways that various actors, both internal and external, perceive that place, and is shaped by shared history and traditions, cultural foundations, the environment(s), and sense of community (Campelo et al., 2014; Nunkoo and Gursoy, 2012). Because places cannot formulate a sense of self independent of human actors, island identities are created and co-created, and then communicated through a variety of channels (Burholt et al., 2013; Campelo et al., 2014; Skinner, 2018). One such channel is the messaging produced to market islands as tourism destinations to various audiences.

In marketing, a brand identity comprises the attributes or characteristics that separate one brand from another and highlight its uniqueness (DeChernatony, 1999). Brands serve as a means to make connections between a product (in this case, an island) and various audiences, and employ a variety of strategic components, including symbols, logos, slogans, or other visual representations meant to easily distinguish one brand from another (Blair et al., 2015; Hankinson, 2009; Lange-Faria and Elliot, 2012). As with all brands, the branding used for island tourism destinations is a marketing tactic designed to succinctly express a specific identity in often simplistic and sometimes cliché formats. If being an island is a desirable factor in attracting visitors, presumably islands would emphasize being an island as part of their brand identity. However, the pre-existing "generic" island brand referenced by Baldacchino (2010, p. 390), along with the paradoxical marketing demand to simultaneously adhere to and differentiate from that trope, poses challenges for effective branding of island destinations.

The current study examines the themes used by island destinations in their tourism logos to help shape their brand identities. Islands, like other tourism destinations (and brands in general), embed themes in their logos to create a brand identity and to communicate with target audiences. By identifying and analyzing recurrent themes in island destination tourism logos, this study seeks to provide valuable insight for island scholars in terms of island identities as they pertain to tourism, as well as how those identities link to residents' understanding of their island(s). This study also aims to aid tourism scholars in better understanding the ways that islands choose to identify themselves to various audiences through their destination brand, as well as inform tourism marketers about the branding identities employed by island destinations, which may in turn assist them in developing effective branding strategies for their client destinations.

\section{The Literature}

The literature related to island identity, island tourism, island branding, and brand identity are all pertinent to the discourse in this paper. The study of islands as a discrete stream of scholarship has yielded important research related to the unique place that islands occupy in the minds of tourists and residents alike, the characteristics (or 'identity') that make islands different from their non-island counterparts, and the reliance that many islands have on tourism as a vital 
economic driver (Seetanah, 2011). As part of the development of islands' tourism industries, destinations engage in both place branding and tourism branding. Tourism branding shares many of the key components of marketing in general, but the application to the tourism sector offers unique perspectives relevant to this study (Rowett, 2016). Both branding approaches contribute to brand identity development. The following review of the scholarly literature will examine each of these themes in detail.

\section{Islands and Island Identity}

According to Stets and Biga (2003, p. 401), identity is "a set of meanings attached to the self that serves as a standard or reference that guides behaviour in situations." Identity theory provides a conceptual framework through which the linkages "between identity, attitude, and behavior" (Nunkoo and Gursoy, 2012, p. 244) are examined and understood. That is, identities are those which the person (or, in this case, the place) claim as theirs, accompanied by all the requisite meanings, including pluralities of identity. While a rather robust theoretical model in some academic spheres, identity theory has had limited use with respect to islands or in relation to tourism (Nunkoo and Gursoy, 2012). The emerging but related field of place identity applies the principles of human identity to places in an effort to understand the manifestation and communication of identity of a geographic location, by which 'island identity' can be said to reflect the personality or characteristics associated with an island destination (Baldacchino, 2003; Berrozpe et al., 2017; Hay, 2006; Loureiro and Kauffmann, 2013).

Part of an identity framework includes the notion of cultural identity, whereby people and places are reflected through the manifestation and expression of the culture within which they live, were raised, and experience the world (Bhabha, 2012; Campelo et al., 2014; Marker, 2000). Because culture is a human construct and is dynamic rather than static, cultural identity changes over time in response to environmental stimuli, both natural and human-made. This cultural identity includes the impacts that colonialism has had throughout history in terms of conquering, decimating, eradicating, coopting, and erasing Indigenous cultures. A fundamental part of colonization is the devaluing and elimination of Indigenous cultures and its replacement with the cultural identities of the oppressors (Nimführ and Meloni, 2021). While the decolonization movement is attempting to revitalize and re-establish lost or marginalized cultural identities, this process is hindered by the perpetuation of imbalances in both power and agency and the diaspora of peoples with connections to Indigenous identities that has resulted in the disbursement around the globe (Hall, 1990; Nadarajah and Grydehøj, 2016; Nimführ and Meloni, 2021).

Island identity considers the identity of a place based on linkages to islandness and how islandness shapes perceptions of self for the place, as interpreted by different individuals in different contexts. Baldacchino $(2003$, p. 273) explains that island identity is "a situational feature" in which the nature of being an island shapes the perception of self, both intrinsically and extrinsically. Since islands themselves have no ability for conscious thought, and therefore cannot have a sense of self, island identity as it pertains to place is externally constructed by those who engage with the island place and who are influenced by the place's islandness. In addition, because islands have long and storied histories of colonization, its profound impacts on the island identity that cannot be ignored or brushed aside (Grydehøj, 2018).

Because it is constructed, sustained, changed, and interpreted by various parties, island identity can be a nebulous, porous, and contested concept. When considering both the collective island identity and individual island identities, there is no consensus on what it means to be an island, what constitutes islandness, what island identity comprises, or who gets to decide (Conkling, 2007; Hay, 2006, 2013; Grydehøj, 2020). Burholt, Scharf, and Walsh (2013) suggest that island 
identity, like all notions of identity, is performative in that it must be expressed and interpreted both individually and collectively. That is, identity is co-constructed or co-created to fit the purposes and objectives of various parties and is then institutionalized through "interlinked practices, ideas, artefacts, behaviours, and values" (Burholt et al., 2013, p. 2; Skinner, 2018). Factors such as geographic boundedness, unique socio-political realities, natural environment, relative size, historical context (including colonization and colonial legacies), and sense of community all contribute to the formation of identity (Anderson, 2003; Burholt et al., 2013; Cottrell, 2017; Weale, 1991, 1992). Rather than being static, island identity is continually renegotiated in response to a range of internal and external drivers; a dynamic process which considers diverse audiences and stakeholders, each of whom participate in their own creation, co-creation, and meaning-making of a place in relation to identity (Canavan, 2017; Skinner, 2018).

The negotiation of island identity, including who shapes that identity, how, and for whom, is often deeply rooted in colonialism. Detangling the intricacies of identity from its colonial influences and permeation into the soul of a place, its people, and its cultural expressions is challenging and power- and perspective-dependent (Escobar, 2003; Grydehøj, 2018; Nadarajah and Grydehøj, 2016). Sussing out Indigenous cultural identity from the ravaging effects of colonialism is hindered by the pervasiveness and totality of colonizers' 'success' in coercing, erasing, punishing, and bastardizing the subjugated populations for the benefit of the colonizers. If Indigenous populations survived, their cultural identity likely did not - at least not unscathed. Attempts to reclaim aspects of those lost identities is framed by the continuing legacy of colonization which colors and impedes a return to Indigenous roots (Stratford, 2003). Because of the co-created nature of identity, and both its internal and external manifestation by various actors, these identities are often embedded with and interpreted through a colonial framework (Baldacchino, 2013). The power and agency to influence or shape identity is often centralized through political, economic, and social systems that privilege some while marginalizing others, and historically Indigenous communities have been left out of those systems (Sulistiyono and Rochwulaningsih, 2013). The decolonization project, in island studies discourse, challenges scholars to consider the colonial origins of the islands that they study, including the impact of colonialism and decolonialism in terms of both subject and process, and provides space for non-Eurocentric perspectives and knowledge (Nadarajah and Grydehøj, 2016).

\section{Island Tourism}

Islands have a long-established allure and romanticism for travellers the world over (Baldacchino, 2012; Péron, 2004). Baldacchino (2012, p. 55) proposed that the island brand has existed for hundreds of years, observing that current perceptions of islands are "part myth, part marketing hype, and part reality" and that islands are presented in media, literature, arts, and history books as "platforms of paradise," "locales of desire," and "habitual sites of fascination". The archetype of the island as intricately linked to water, land, and boundedness permeates "language, myths, and works of art" (Lugovskoy, 2015, p. 176; Brinklow, 2013) such that its understanding is sometimes perceived as singular, despite a rich diversity of islands dotting planet Earth. As Brunhes (1920, pp. 160-161) articulated, "an island's 'signature' is its obvious optic: it is a geographically finite, total, discrete, sharply precise physical entity which accentuates clear and holistic notions of location and identity." Islands hold a special place within tourism by virtue of their islandness alone, and Baldacchino (2016) has made a compelling argument for the power of the island brand: islands are highly regarded and integral in terms of economic, political, cultural, and social contributions; islands are exotic and extol both innocence and hedonism simultaneously; islands project themselves as idyllic; and many islands can grow their economic base by exploiting the sun, sand, and sea. 
Islands, particularly those with a strong economic dependence on tourism, are often complicit in perpetuating the narrowly defined constructs of their essence by playing up those aspects that align with the prevailing generic island brand (Baldacchino, 2012; Baldacchino and Khamis, 2018). This propensity presents two problems. First, as island destinations work to differentiate themselves from other islands for the purposes of brand development, the focus or emphasis on generic islandness may impede meaningful distinctions among and between destinations. Secondly, islands that are looking to expand their economic base beyond traditional tourism may struggle to create a place identity which incorporates their attractiveness as a tourism destination while also highlighting characteristics associated with other desirable economic opportunities (Baldacchino, 2010; Baldacchino and Khamis, 2018).

Tourism is an important economic engine for many islands around the world and, accordingly, the academic discipline of Island Studies includes robust discourse on tourism as it pertains to islands. Although some scholarly critics have argued that nothing of note differentiates an island from any other small(ish) and/or isolated geographic region (Butler, 2012; Selwyn, 1980), other voices have heralded the unique, interesting, and compelling investigation into islands as a distinct, multi-disciplinary, and worthwhile academic pursuit (Baldacchino, 2003, 2008; Baum, 1997; McCall, 1994). Similarly, some scholars maintain a distinction between 'island tourism' and 'tourism on islands': the former describing tourism as taking place in a specific type of location as its primary and most notable feature, and the latter encompassing the policies and practices of tourism as relevant to islands (Butler, 2012; Sharpley, 2012). While Butler (2012) opined that for island tourism to be more than simply tourism that occurs on islands, there must be something intrinsic about islands that in and of itself warrants touristic exploration. Sharpley (2012) asserted that islands are no different from non-islands with respect to tourism and are therefore unworthy of specific attention within tourism studies. The volume of scholarly activity focusing on all connotations of island tourism demonstrates that many island scholars disagree with both views, maintaining that islands offer a unique, compelling, and important touristic perspective that is indeed worthy of investigation in its own right (Almeida-Santana and Moreno-Gil, 2018; Baldacchino, 2010; Baldacchino and Khamis, 2018; Baum, 1997; Vannini and Taggart, 2013).

Colonialism and colonization are embedded in island tourism. The tourism industry continues to benefit those with privilege and exploit oppressed populations through economic systems whereby access to capital resources, decisionmaking, and profits are the domain of colonizers. While local Indigenous populations may work in the tourism sector, the positive outcomes of tourism (profit and power) remain with the privileged, while the negative outcomes of tourism (pollution and environmental degradation) disproportionally impact Indigenous populations. Increasingly, consumers are becoming aware of issues related to social justice, including the legacy of colonization, and are making consumer decisions that align with values tied to social justice causes. Tourism destinations are responding by indigenizing tourism offerings but too often these initiatives are not led by or do not benefit Indigenous communities, and instead represent the continued appropriation and exploitation of Indigenous cultures (Belisle, 1983; d'Hauteserre, 2010; Weaver, 2016).

\section{Branding and Brand Identity}

The application of branding principles and practices to geographic destinations is relatively new (Almeyda-lbáñez and George, 2017; Baldacchino and Khamis, 2018; Blain et al., 2005, Johnson, 2012). Place branding helps a location - be it a municipality, province/state, region, or nation - advance its objectives by creating a brand identity that positions the place in the minds of its key audiences, and the study of place branding constitutes a distinct yet interdisciplinary 
academic field that marries marketing (specifically, branding) with a locale's geographic, political, social, and economic identity (Briciu and Briciu, 2016; Campelo et al., 2014; Dziuba, 2015; Kahn, 2006; Kilduff and Nunez-Tabales, 2017). Place branding is a complex process with competing agendas, various stakeholders, and diverse place attributes all vying for inclusion within the brand identity itself and, while often used for tourism purposes, it also plays a role in establishing a place identity within the contexts of investors, immigrants, exports, skilled labour, and natural resources (Blair et al., 2015; Briciu, 2013; Grydehøj, 2008; Konecnik et al., 2012; Yusof et al., 2014). In light of this complex intersectionality, place branding researchers are often skeptical about the practicality of trying to succinctly capture the diverse nuances and perspectives of a place through a brand, as competing priorities make it difficult to reduce the dynamic essence of a place into a singular all-purpose brand identity (Anholt, 2008; Baldacchino and Khamis, 2018; Bernardie-Tahir and Schmool, 2014; Grydehøj, 2008; Petrea et al., 2013).

With respect to developing and designing a place brand, many different approaches have been suggested. Aitken and Campelo (2011) have argued for the consideration of the ' 4 Rs': rights, roles, relationships, and responsibilities; a process which may help clarify the brand purposes, address concerns from various audiences, establish buy-in or support for the brand, and institute a brand identity. Hayward and Kuwahara (2014) provide further advice for stakeholders: prioritize the characteristics (identity) that best reflect the image to be portrayed. Beritelli and Laesser (2016) caution that tourism brand developers relying on generic images may end up with a brand identity that entails uncompelling communications and vague meanings, resulting in a singular and simplistic brand that says little about the true identity of the destination (Bregoli, 2013). In line with this caution, a 2010 study examining the brand identities of six Dutch Caribbean islands found few discernable differences (Daye, 2010). Given that one of the main purposes of branding is to help audiences distinguish between two or more brands through unique identities, such lack of distinguishability can be problematic and costly.

Any kind of branding, including place branding, requires the establishment and communication of a brand identity. Each component of that brand identity is vital in the creation and propagation of a destination brand, and destinations develop and promote symbols to help convey their unique characteristics, personality, and image, thereby creating a distinct and meaningful identity (Kladou et al., 2016; Lee et al., 2012). One means of understanding a destination's brand identity is to examine its expression through its logo (Kim and Lim, 2019; Sadler et al., 2016). A logo is the visual and symbolic representation of a brand and is intricately linked to a brand's identity (Beritelli and Laesser, 2016; Kim and Lim, 2019; Lee et al., 2012; Seraphin et al., 2016). Many studies have found positive relationships between brand logos and consumer attitudes and intentions, proffering a valuable reminder about "the importance of the affective reactions logos can generate" (Lee et al., 2012, p. 589; Kim and Lim, 2019).

Logos are only one aspect of a destination's branding strategy; other components of a brand's architecture may include a slogan, spokesperson, or jingle, as well as photographs, videos, and text (Datzira-Masip and Poluzzi, 2014). While each component is different, brands often embed common elements throughout, thus leveraging one piece of the brand's architecture off of others to form a cohesive, consistent brand image. Disparate brand components can cause confusion and reduce impact, and such misfires can come at a high cost. To mitigate such issues, some places opt to develop distinct and effective brands for different target audiences, as in Iceland's promotion of their tourism (Inspired by Iceland), product export (Iceland Naturally), and environmental (Green by Iceland) endeavours (Íslandsstofa, n.d.; TangTaye and Standing, 2016; Wheeler et al., 2011). While such approaches often allow for overlap across brand identities and objectives, they can also result in a set of distinct, incongruous brands. As such, to ensure clarity, the current study focuses solely on island brand logos which had been developed for the purpose of tourism promotion. 
To be effective, tourism branding messages need to resonate with several key stakeholders, further adding to the complexity of developing a distinctive and clear brand identity (Briciu, 2013; Briciu and Briciu, 2016). Tourism branding targets potential visitors - both those who have visited before and those who have not - whose prior knowledge of the locale can vary greatly. As a result, destinations that use less well-known or more implicit themes in their logos may not connect with potential visitors for whom those themes have no meaning (Katz, 2018). That said, as effective tourism branding aims to connect with the place's identity and ideals as experienced by local residents, it is critical that the brand identity aligns with those upheld by operational and community stakeholders representing the brand on a more micro level (Almeyda- Ibáñez and George, 2017; Bonn and Brand, 1995; Canavan, 2017; Grydehøj, 2008; Whitten Henry, 2020). Disparity between how the brand identity is portrayed to potential visitors and how locals understand their place can cause dissonance and resentment among residents, negatively impacting community buy-in, engagement, and support of the industry (Almeyda- Ibáñez and George, 2017; Campelo et al., 2014; Canavan, 2017; Grydehøj, 2008; Popescu, 2014). This gap and resulting tension may also hamper the actual experience of tourists when they visit the place, as their affirmation of the brand's identity relies in part on their engagement with products and experiences (AlmeydaIbáñez and George, 2017; Campelo et al., 2014).

The legacy of colonization also shapes the branding process in terms of whose sense of identity is captured and how in the development of a brand identity. First, the voices heard throughout the branding process tends to be those with the power and agency to exercise their privilege through systems that value these perspectives over others (Neilsen and Wilson, 2012). Second, the local culture that is being captured via branding is already permeated with the vestiges of colonization and those influences cannot be easily detangled or extricated to find more Indigenous identities (Carr et al., 2016). Lastly, the audiences for which brand identities are designed often identify with the oppressor and thus brands are imbued with colonial identities rather than Indigenous ones to appease those audiences. (Sroypetch, 2016) Even when Indigenous identities are incorporated into branding, such as with many of the brands associated with the Hawaiian Islands, it is done with the purpose of appealing to audiences who value (at least superficially) Indigenous - or quasiIndigenous - Hawaiian identities, but these identities are often appropriated by the colonizers for exploitation, rather than being rooted in the Indigenous communities themselves. Branding can be a reinforcing mechanism of colonization by perpetuating the colonized identity as legitimate to a wide audience who often demonstrate little interest in seeking to understand Indigenous identities or the colonial histories that have shaped the places they visit. For example, the brand identity of Bermuda as a tourism destination emphasizes its colonial history through the promotion of high-tea, cricket, attire (Bermuda shorts), pub-culture, and left-lane driving, and espouses opportunities to 'celebrate' Bermuda's colonial history.

Many of the findings in tourism branding research can be applied to all destinations, but there are several contributions that are unique and specific to islands (Baldacchino, 2012; Baldacchino and Khamis, 2018; Daye, 2010; Henthorne et al., 2016; Leseure, 2010). Daye (2010) observed that many islands have difficulty expressing points of difference in their branding strategies and brand identities as compared to other island destinations, instead opting to focus on points of parity. In examining the unique selling positions of Caribbean destinations, Henthorne and colleagues (2016) and also noted that sustained points of differentiation were a challenge and that, over time, a convergence of positions emerged. Baldacchino (2012, p. 58), when discussing island branding in the context of commodification, indicated that the representation of an island space "may be geared primarily for outsider (such as visitor) consumption" rather than as locals would see it, an approach which may be valuable in terms of selling the appeal of the destination but, as previously discussed, may have negative implications on the ground (Grydehøj, 2008). Many island branding messages are imbued with their essence or (projected) personality, for example Skye is 'breathtaking' while Turks and Caicos are 
'beautiful by nature' (Leseure, 2010), and many colder island destinations have found success through messages that "emphasise either clean and unspoilt spaces ripe for nature based, adrenalin pumping adventure and discovery" or "historical episodes [...] such as Viking traditions in Shetland" (Baldacchino, 2012, p. 59).

Island identity, island tourism, island branding, and brand identity each have their own scholarly discourse and are represented to various degrees in the academic literature. The review of the research related to these concepts, individually and collectively, provides a foundation from which this study intends to proceed in an effort to add to the body of knowledge pertaining to island identity and brand identity, and their union.

\section{Method}

The current study examined a selection of island tourism logos with the purpose of answering the question: what themes are used by island tourism destinations, via brand logos, to help establish the island's identity? Several steps were taken when assembling the research sample. A preliminary list of popular island tourism destinations was compiled, based on the systematic review of a variety of published lists of the most popular island tourism destinations, sourced from travel-related magazines and websites and covering a range of destination types, including cities, regions, states/provinces, countries, islands, and attractions. This review resulted in a preliminary list exceeding 140 islands, archipelagos, island clusters, and sub-island jurisdictions. The tourism logo for each destination on the preliminary list was sourced based on the following criteria: 1 ) it was the most recent logo (to the extent it was possible to discern); 2) it was used specifically for tourism marketing; 3 ) it was linked to the destination itself, rather than to a specific tourism industry body; and 4) it consisted primarily of a graphic image, without photography or extraneous text beyond a brief slogan. Based on these criteria, more than 60 islands were eliminated, leaving a final list of 84 islands (see Table 1).

Table 1. List of island destinations whose tourism logos were included in the sample.

\begin{tabular}{|c|c|c|}
\hline $\begin{array}{l}\text { Anguilla } \\
\text { Antigua and Barbuda } \\
\text { Aruba } \\
\text { Bahamas } \\
\text { Bali } \\
\text { Barbados } \\
\text { Bermuda } \\
\text { Bonaire } \\
\text { British Virgin Islands } \\
\text { Cayman Islands } \\
\text { Canary Islands } \\
\text { Cape Breton } \\
\text { Cape Verde } \\
\text { Capri } \\
\text { Catalina Island } \\
\text { Cook Islands } \\
\text { Cozumel } \\
\text { Crete } \\
\text { Curaçao } \\
\text { Cyprus } \\
\text { Dominica } \\
\text { Dominican Republic } \\
\text { Easter Island } \\
\text { Faroe Islands } \\
\text { Fiji } \\
\text { Florida Keys and Key West } \\
\text { Gozo }\end{array}$ & $\begin{array}{l}\text { Greenland } \\
\text { Grenada } \\
\text { Guam } \\
\text { Haiti } \\
\text { Hawai'i } \\
\text { Hilton Head Island } \\
\text { Hydra } \\
\text { Iceland } \\
\text { Indonesia } \\
\text { Ireland } \\
\text { Jamaica } \\
\text { Kangaroo Island } \\
\text { Kaua'i } \\
\text { Lāna'i } \\
\text { Madeira Islands } \\
\text { Magdalen Islands } \\
\text { Maldives } \\
\text { Malta } \\
\text { Martinique } \\
\text { Mauritius } \\
\text { Moloka'i } \\
\text { Mykonos } \\
\text { Nantucket } \\
\text { Nevis } \\
\text { New Caledonia } \\
\text { New Zealand } \\
\text { O'ahu } \\
\text { Orkney }\end{array}$ & $\begin{array}{l}\text { Outer Banks } \\
\text { Outer Hebrides } \\
\text { Palawan } \\
\text { Papua New Guinea } \\
\text { Philippines } \\
\text { Prince Edward Island } \\
\text { Rhodes } \\
\text { Sabah } \\
\text { Saint Lucia } \\
\text { Samoa } \\
\text { Santorini } \\
\text { Sardinia } \\
\text { Seychelles } \\
\text { Shetland } \\
\text { Solomon Islands } \\
\text { St. Kitts } \\
\text { Sint Maarten } \\
\text { Saint Martin } \\
\text { St. Vincent and the Grenadines } \\
\text { Tahiti } \\
\text { Tasmania } \\
\text { Tonga } \\
\text { Trinidad and Tobago } \\
\text { Turks and Caicos } \\
\text { US Virgin Islands } \\
\text { Vanuatu } \\
\text { Whitsundays } \\
\text { Zanzibar }\end{array}$ \\
\hline
\end{tabular}


The study blended two methodologies: content analysis and thematic analysis. Content analysis, popular in communications research, is used to determine and quantify the presence of certain words, concepts, themes, or phrases within communication items (such as documents, pictures, audio, or video) and assign meaning to the items being analyzed, in this case elements of tourism logos (Krippendorff, 1989). This approach was blended with thematic analysis, which clusters and categorizes data into themes based on observed patterns, enabling meaning to be extracted and considered from a more holistic perspective (Aronson, 1995; Braun and Clarke, 2012).

Three researchers, including one faculty member (Faculty of Business, Marketing) and two graduate students at the University of Prince Edward Island simultaneously reviewed each logo to identify, discuss, and record observed embedded themes, drawn from explicit or implicit images, symbols, or patterns within the logo. In instances where discrepancies or disagreements arose around particular logo elements or themes, the group shared their perspectives and ultimately came to a consensus. The reviewers permitted themselves to conduct supplementary research to help clarify whether a theme was present (e.g., search the internet for the colours in a destination's flag to see whether they aligned with the colours in the logo). Each of the logos generated varying amounts of discussion depending on their complexity or uniqueness but, overall, consensus on the observed themes was easily reached. The results of the content and thematic analysis for each of the island tourism logos were synthesized and grouped, both qualitatively and quantitatively. Several recurrent themes were identified and grouped into higher-level clusters. The results of the data analysis follow.

\section{Results}

Logo themes help to shape each island's brand identity as unique and distinct from other islands, while also serving to connect the island with other islands as part of an overall island brand. A careful and systematic review of island tourism logos revealed several recurrent themes and theme clusters embedded in island tourism destination logos. Overall, four major theme clusters emerged - colours, flora and fauna, landscapes and seascapes, islands - and are discussed below.

\section{Colours}

Many island tourism logos incorporated vivid colours as part of the overall design. For some island logos, those colours were limited to one or two, while many featured a broader spectrum. Twenty-three (23) logos incorporated more than three bright or vivid colours in prominent ways, with islands such as Aruba, Cape Verde, and Gozo using punchy, bright colours and rainbow elements that made their logos stand out.

Of the 84 island tourism logos reviewed, 40 incorporated one or more shades of blue as a main colour. These blues ranged from dark to light, and a single logo often featured various hues. Blue was also used in various ways to explicitly denote or represent water (e.g., Cozumel, Iceland), to reference sky (e.g., Capri, Orkney), as a font colour (e.g., Antigua and Barbuda), or in a more abstract manner (e.g., Crete). Green was also frequently and prominently used, appearing as a dominant colour in 20 island tourism logos. Dominica's entire logo is green, as is that of New Caledonia. Often used to depict flora or land, the greens used in many of the logos were verdant and lush. Other prominent colours were yellow (13), orange (11), red (11), and pink (3). Very few island tourism logos feature 'dull' colours, although islands such as Moloka'i used brown - along with green - to create an 'earthy' motif. 


\section{Flora and Fauna}

A variety of flora and/or fauna were depicted in 19 island tourism logos. Twelve (12) of these included images of flowers, which were often specific and native or notable to the destination. Flowers featured prominently in the logos of many destinations, including Canary Islands, Madeira Islands, Martinique, Seychelles, Sint Maarten, St. Vincent and the Grenadines, and Tahiti. Four (4) logos featured trees, the majority of which were palm trees (3), as seen in the logos for Antigua and Barbuda, Palawan, and Sabah. Another five (5) logos included other plants of some kind. For example, Grenada's logo incorporated the nutmeg plant while Ireland's logo included an image of a shamrock. With respect to fauna, sixteen (16) logos included images of a land animal or sea creature, including nine (9) logos with birds, both specific, such as Bonaire's inclusion of a flamingo, and generic, as seen in the logos of Prince Edward Island and St. Vincent and the Grenadines. Other fauna included fish (Barbados, Kangaroo Island, Maldives), a turtle (Cayman Islands), a monkey (Sabah), a snail (Sardinia), a butterfly (Nevis), a chameleon (Rhodes), and a 'tiger' (thylacine; Tasmania).

\section{Landscapes and Seascapes}

Well-defined landscapes and seascapes were featured in nine (9) island tourism logos, often depicting a beach scene with lush greenery in the background. Notable among these were the logos for Catalina Island, Dominica, Magdalen Islands, Orkney, Sabah, and St. Kitts, each of which portrayed picturesque scenes. Other logos, such as those of Dominican Republic and Saint Lucia, used more rudimentary or abstract representations of landscapes or seascapes.

The sun featured in sixteen (16) logos, sometimes in the form of sunrise/sunset, sunlight, or rays of sunshine (e.g., Curaçao, Cyprus, Dominican Republic, Palawan, Rhodes, Solomon Islands). Several logos, including those of Canary Islands and Papua New Guinea, portrayed the sun as light emanating from the logo itself. Other aspects of landscape- or seascape-based logos included images of waves (19) and hills or mountains (6). Logos for Cape Breton Island, Cozumel, Dominican Republic, Mauritius, Prince Edward Island, and Tasmania all featured a single wave, while those of British Virgin Islands, Cyprus, Iceland, New Caledonia, Rhodes, Seychelles, and Saint Lucia featured multiple waves. 'Wavy' fonts were used by Barbados, Bermuda, Mauritius, Outer Banks, Tasmania, and Turks and Caicos. The logos for Saint Lucia, Cape Breton, St. Kitts, Dominica, Magdalen Islands, and Sabah all feature hilly or mountainous backdrops.

\section{Islands}

Forty-seven (47) logos featured aspects of islandness or a notable nod to the destination's geographic identity as an island. Twenty-four (24) of these logos incorporated the shape of an island or islands (e.g., Bahamas, Crete, Dominica, Florida Keys and Key West, Kangaroo Island, Outer Banks, New Zealand, and Sardinia). Sixteen (16) destinations' names (and, therefore, their logos) included the word island, and eight (8) logos featured the word island in the embedded slogan within the logo, such as Aruba's "One Happy Island” and Crete's "The Island Inside You."

\section{Other Themes}

Several additional themes emerged which were prominent throughout the dataset but did not fit into any of the four main theme categories outlined above. Ten (10) logos alluded to their jurisdictional status, linking to metropoles or other 
jurisdictions with which they were associated. Four of the five Hawaiian islands' logos included in the study made reference to being a part of the greater archipelago (and State) of Hawai'i in their embedded slogan. Kaua' i branded itself as "Hawaili's Island of Discovery," Lāna'i claimed to be "Hawai'i's Most Enticing Island," Moloka' i used the slogan "Hawaiian by Nature," and O'ahu's slogan was "The Heart of Hawai'i," while the "Big Island" of Hawai'i references the greater Hawaiian islands in its name. The logo of the British Virgin Islands made reference to their status as colonized overseas territories through the logo color scheme as well as in the destination's name. Additionally, Outer Banks made reference to North Carolina, Hilton Head Island linked to South Carolina, and Sabah noted its relationship to Borneo. Additionally, many destinations featured recognizable or 'iconic' characteristics in their logos. For example, eight (8) destinations used colours in their logos that mirrored or referenced those in their flag (e.g., Greenland, Iceland, Saint Lucia, and Tonga).

\section{Discussion}

\section{Islands, Island Identity, and Island Tourism}

The enduring and well-established allure of the island continues to draw visitors to island destinations in search of an idealized getaway (Baldacchino, 2012; Lugovskoy, 2015; Péron, 2004). While some have argued that islands do not differ from non-islands in any meaningful touristic manner, a plethora of scholarly research championing islands' islandness and examining island tourism as a specific subsection of tourism suggests otherwise (Butler, 2012; Sharpley, 2012; Baldacchino and Khamis, 2018). The present findings indicate that an island identity is a critical factor in attracting tourists, although is often employed in tandem with other key themes. To help prospective visitors make the connection between a particular destination's island identity and the quintessential island escape, 41 of the 84 tourism logos analyzed in the current study contained allusions to the destination's islandness, whether through the destination name, branding slogan, or visual elements of the logo itself. In addition, many of the island tourism logos used themes which have been found to be associated with islandness, including those related to water, nature, and history or tradition (Brinklow, 2013; Graham, 2020). In many instances, water was expressly represented through the depiction of waves, and was widely implied through incorporation of the colour blue. Nature was highlighted in logos in the form of flora and fauna, and depictions of landscapes and seascapes, while connections to history and tradition - as represented by references to a flag or by linking to other geographic jurisdictions - were also prevalent. Overall, the findings suggest that an island identity was a key element in many destinations' strategic brand identities.

While the current study affirms the uniqueness of islands as tourism destinations, Sharpley's (2012) contention does hold some merit when considering the fundamental attributes of one subsector of the tourism industry: the ' $3 S^{\prime}$ ' trifecta of "sun, sand, and sea" (Baldacchino, 2012, p. 56; Cameron and Gatewood, 2008). Many islands can boast all three pillars of touristic pursuits, so it should be no surprise that these elements appear in many of the island tourism logos analyzed in this study, representing part of their island and brand identities. Of the 84 island tourism logos analyzed, 30 included at least one element relating to themes of sun, sand, or sea, while several included two themes, and some included all three. Yet, sun, sand, and sea are not exclusively the domain of islands; many coastal destinations around the world can also lay claim to this recipe for vacation bliss. Consequently, islands are not only competing against other islands for a share of the $3 \mathrm{~S}$ tourism market, but must also compete with coastal mainland destinations sharing these desired features. The 3Ss can hardly be considered a distinguishing feature when there is an abundance of destinations, both 
island and mainland, that share the same characteristics (Cameron and Gatewood, 2008; Conway and Timms, 2010; Maloney and Montes Rojas, 2005; Stupart and Shipley, 2012). While some 3S-focused island destinations attempt to set themselves apart by laying claim to the 'most beautiful beaches,' 'most spectacular sunsets,' and 'most crystal-clear waters' as part of their 'distinct' island identity, much of this is subjective hyperbole. In truth, finding meaningful differences between many of the $3 S$ destinations can be challenging (Daye, 2010) and, therefore, the strategy of employing the lure of 'sun, sand, and sea' as the bedrock of a destination's brand identity seems ineffective when establishing a unique brand identity for an island destination.

\section{Island Identity, Place Branding, and Tourism Marketing}

Place branding strategies often target a variety of audiences for various purposes, even within the narrow confines of tourism marketing (Anholt, 2008). These audiences may include potential visitors, previous visitors, tourism operators, local residents, and government stakeholders, each with different needs and expectations in terms of what the brand identity conveys (Hem and Iversen, 2004). Critics note that developing brand identities to appeal to various audiences with diverse needs can result in ineffective branding strategies and a muddled brand identity (Bernadie-Tahir and Schmool, 2014; Grydehøj, 2008). To further complicate matters, consumers are playing an increasingly greater role in the creation or construction of brand identity, deciding and communicating a brand's identity for themselves rather than assuming a passive role and being told by brand managers what the brand's identity is or means. Thus, establishing a brand - and the accompanying brand identity and architecture - is a complex, multi-faceted, and dynamic exercise that must balance the needs of various stakeholders, destination objectives, and limited resources.

A brand's purpose is to help communicate vital information to audiences which assists them in understanding the brand identity and in making decisions in terms of their impressions, attitudes, and purchase decisions (Campelo et al., 2014; Daye, 2010; Henthorne et al., 2016; Kim and Lim, 2019). One communication method is to highlight points of parity: the ways in which the brand's identity is similar to others in the product category. Including these points of parity helps to establish brand identity familiarity among audiences, which in turn can foster positive associations as well as help audiences understand and accept the new brand identity within the context of their knowledge of other brands. Points of parity also help to reduce perceived risks for newer audiences by establishing a framework for understanding the brand in relatable terms. Over emphasis on points of parity, however, can result in a brand identity that is indistinguishable from another brand, and is thus uncompelling. To mitigate this, effective brands also incorporate points of difference to highlight the ways in which their brand identity differs from others in the product category (Keller et al., 2002). Some of the overarching consistency of the themes observed in the current study - particularly the use of bright colours (especially blue and green), depiction of flora and fauna, and emphasis on being an island - may serve as compelling points of parity to help audiences relate to and establish a sense of familiarity with these island destinations. Even when incorporating relatively common themes, however, each tourism logo in the current sample remained distinct and unique, thus aiding in establishing points of difference between island destinations. This was perhaps most notable in the tourism logos that included a slogan, as the slogans often identified and specified a point of difference for the island destination. For example, 'Fiji - Where Happiness Finds You,' 'Lāna'i - Hawaili's Most Enticing Island,' and 'Cape Breton Nova Scotia's Masterpiece' each highlight ways in which the island destination is different or special.

The connections between familiarity and branding are well researched, and academic literature has identified clear differences in audience responses between individuals who are familiar with a brand and those who are less (or not) 
familiar (Delgado-Ballester et al., 2012; Herm and Moller, 2014; Kim and Lim, 2019). Familiarity, linked to brand recall and recognition (Marti, 2005), has been found to enhance destination image and intention to visit (Bigne et al., 2019), brand attachment (Grobert et al., 2016), brand trustworthiness (Katz, 2018), and customer-based brand equity (DelgadoBallester et al., 2012). Notably, familiarity is also linked to brand identification (Herm and Moller, 2014), which may explain the connection between destination familiarity and the ability to recognize related themes. With a variety of brand identity components employed to connect with differing audiences - each with their own needs, expectations, and brand knowledge - individual components which target specific audiences may not resonate with all audiences. For instances, some logos incorporate themes which may be unfamiliar to audiences who have not yet visited the destination but which are in fact very meaningful to local residents, industry stakeholders, and previous visitors. The meaning of themes embedded in a logo are often deliberate on the part of the brand developers, but audiences may also attribute meaning that stems from other information sources, including their own experiences with the brand (in this case, the island place). This transference of symbolism occurs with dynamic branding, whereby brand meaning evolves over time, and is shaped by both the brand itself and consumers who increasingly define brands on their own terms (Helm and Jones, 2010). As islandness is itself a dynamic construct, brand developers who recognize and embrace this rich parallel are sure to deliver impactful, compelling, and meaningful island destination brands.

\section{Decolonialism and Island Identity}

The studied islands have various histories with respect to colonialism. Many of the Caribbean, South Pacific, and Mediterranean islands have colonial legacies, and even long after the process of decolonization has begun, the taint of colonialism remains pervasive and difficult to extricate (Dumontet et al., 2019). During colonization, Indigenous cultures were decimated through genocide, enslavement, punishment, and exclusion from political, economic, and social participation - some of which continues to this day. The embedded nature of colonialism means that decolonization is a messy, imperfect, non-linear, contested, negotiated, and volatile endeavour (Nadarajah and Grydehøj, 2016). The institutionalization of colonialism, its entrenchment into the local culture, and the ways in which it shapes thoughts and knowledge make incremental progress challenging. Even the act of identifying and naming themes observed in the tourism brand logos (and thus identities) is an act of colonialism whereby the privileged and Western-centric perspective of the researchers is the vantage point from which island identity is being investigated, observed, analyzed, and documented (Mignolo, 2011; Nadarajah, 2007). Coupling this reality with the co-created nature of identity, and in particular with who does (or does not) participate in this co-creation, how, and why, it is easy to see the colonial influences on the brand identities of some of the islands examined in this study.

Little is known about the formal development of the brand identities for the island destinations included in this study in terms of who participates, how parties were (or were not) engaged, and how/why decisions were made - but in all likelihood key decisions were being made by political and economic entities including governing bodies, marketing teams located away from the destination itself, or tourism organizations which cater to the needs of a small group of stakeholders. The result is that colonial perspectives often permeate the brand identities developed for tourism purposes (Büscher and Fletcher, 2017). For example, the tourism logo for the British Virgin Islands makes direct ties to colonial roots. Others, like the Hawai'ian islands, reclaim part of their precolonial identities through their branding. From consumers' perspectives, the demand for tourism experiences that, at least in part, expose visitors to Indigenous culture is growing, but the authenticity of both the consumers' interest and the tourism offerings provided is unclear and often favors the perspective of the privileged over the oppressed. 
The version of identity that is captured and conveyed through these brand logos and how power and agency is embedded in the branding process is problematic. The decolonialization project challenges Island Studies researchers to question the imperial lens through which much of their work is conceived, conducted, and disseminated (Nadarajah and Grydehøj, 2016; Nimführ and Meloni, 2021; Smith, 2012). Through this particular study, the researchers acknowledge the singularity of perspective used and embedded in this study, from the islands which were included (only those with English language brand logos and accessible through Eurocentric sources) to the observation of themes (which inherently had to having meaning and/or resonate with the researchers' own lived experiences in order for them to be 'seen'). The contribution of this research to the decolonization discourse rests in the questions it raises (Dumontet et al., 2019). How is an island's identity, and by extension brand identity for islands, created? Who participates in this creation of identities, including brand identities, and how? And for whom are these identities, in particular brand identities, created and why? When examined with decolonization as a cornerstone of purpose and process, this discursive perspective provides a mandate for a grossly unrepresented and important voice. Colonization is a process of erasure and silencing of Indigenous voices, and part of the decolonization process is to hear from and amplify these voices such that the collective knowledge of those who have or are experiencing colonization is central to the discourse.

\section{Limitations and Further Research}

While the current study focused on the identification of themes used by islands in their tourism brands, it focused only on logos. As logos are just one component of the destination brand, these findings and discussion represent only part of the overall branding strategy. To fully understand the range of themes employed by island destinations in their tourism branding and brand identities, a comprehensive review of all branding strategy components (slogans, advertisements, online presence, photographs, videos, etc.) would be required, as it is the combination and dynamic interaction of these branding elements that truly reflects the complete brand identity. Additionally, the current research focused solely on the identification and presence of themes, and did not consider theme salience (e.g., prominent, minor, etc.) or purpose. In some cases, a theme represented a minor part of a logo, while in others it was a focal point. Further analysis of island tourism logos to determine the extent to which themes are used, and in what manner, would provide further insight into the roles of certain themes in brands' identities and inform discussion around incorporation of themes in island tourism branding more generally. Examining the brand developers' intentions (particularly in terms of conveyed meaning and target audiences) in the selection and inclusion of logo themes would also provide additional, measurable insight into their use and effectiveness. Finally, the current study focused solely on tourism logos themes of island destinations; themes incorporated in mainland tourism destinations logos and branding may or may not mirror those used by islands. If islandness is an inherently desirable factor for attracting visitors, the themes used by islands should differ in some way from those used by non-islands. Replicating the current study with a sample comprising logos from both island and nonisland tourism destinations may offer clarity and provide insight into which (and how) themes are employed in island vs. non-island tourism destination logos.

\section{Conclusion}

Islands are "powerful brands unto themselves" (Baldacchino, 2016, para. 6) and long romanticized as ideal getaway destinations. The current analysis of island tourism logos identified many of the characteristics contributing to the island allure. While logo themes constitute only one part of an overall branding strategy, due to their high visibility they are 
central to the successful promotion of a destination and establishment of a brand identity. The current study provides insight into key themes employed by island destinations in this aspect of their tourism branding, and highlights many areas warranting further investigation by island scholars and marketers alike. A greater understanding of destinations' branding strategies and brand identities, particularly in an island context, serves to inform innovative, effective branding, and offers a crucial advantage for island destinations in an increasingly competitive tourism industry.

\section{Acknowledgements}

The authors would like to acknowledge the contributions of Maggie J. Whitten Henry in the development of this paper.

\section{References}

Aitken, R., \& Campelo, A., 2011. The 4 Rs of place branding. J. Market. Manag. 27: 913-933. https://doi.org/10.1080/0267257X.2011.560718 Almeida-Santana, A., \& Moreno-Gil, S., 2018. Effective island brand architecture: promoting island tourism in the Canary Islands and other archipelagos. Isl. Stud. J. 13: 71-92. https://doi.org/10.24043/isj.45

Almeyda-lbáñez, M., \& George, B.P., 2017. The evolution of destination branding: A review of branding literature in tourism. J. of Tour. \& Herit. Serv. Market, 3: 9-17. https://doi.org/10.5281/zenodo.401370

Anderson, M.L., 2003. Norfolk Island: Pacific periphery. IsI. 92: 47-53.

Anholt, S., 2008. Place branding: Is it marketing, or isn't it? PI. Brand. Public Dipl. 4: 1-6. https://doi.org/10.1057/pb.2011.28

Aronson, J., 1995. A pragmatic view of thematic analysis. The Qual. Rep. 2: 1-3. https://doi.org/10.46743/2160-3715/1995.2069

Bhabha, H.K., 2012. The location of culture. Routledge, London.

Baldacchino, G., 2003. The coming of age of island studies. R. of Dut. Geogr. Soc. 95: 272-283. https://doi.org/10.1111/j.1467-

9663.2004.00307.x

Baldacchino, G., 2006. Islands, Island Studies, Island Studies Journal. Isl. Stud. J. 1: 3-18.

Baldacchino, G., 2008. Studying islands: On whose terms? Some epistemological and methodological challenges to the pursuit of island studies. Isl. Stud. J. 3: 37-56.

Baldacchino, G., 2010. Island brands and "the Island" as a brand: Insights from immigrant entrepreneurs on Prince Edward Island. Int. J. of Entrep. \& Small Bus. 9: 78-393. https://doi.org/10.1504/IJESB.2010.032400

Baldacchino, G., 2012. The lure of the island: A spatial analysis of power relations. J. of Mar. Isl. Culture. 1: 55-62.

https://doi.org/10.1016/j.imic.2012.11.003

Baldacchino, G., 2013. Island landscapes and European culture: An 'island studies' perspective. J. of Mar. Isl. Culture, 2: 13-19.

https://doi.org/10.1016/j.imic.2013.04.001

Baldacchino, G., 2016. On the branding and reputation of islands. The PI. Brand Obs. http://www.placebrandobserver.com/branding-islands

Baldacchino, G., \& Khamis, S., 2018. Brands and branding in: G. Baldacchino (Ed.), Routledge International Handbook of Island Studies. Routledge, London, pp. 368-380. Routledge, London.

Baum, T.G., 1997. The fascination of islands: A tourist perspective in: D.G. Lockhart and D. Drakakis-Smith (Eds.), Island Tourism: Problems and Perspectives. Mansell, London. pp. 21-35. 
Belisle, F. J., 1983. Tourism and food production in the Caribbean. Ann. of Tour. Res., 10: 497-513. https://doi.org/10.1016/01607383(83)90005-1

Beritelli, P., \& Laesser, C., 2016. Destination logos recognition and implications for intentional destination branding by DMOs: A case for saving money. J. of Destin. Market. Manag. 8: 1-13. https://doi.org/10.1016/j.jdmm.2016.08.010

Bernardie-Tahir, N., \& Schmool, S., 2014. Opening up the island: A counter-islandness approach to migration in Malta. Isl. Stud. J. 9: 43-56.

Berrozpe, A., Campo, S., \& Yague, M.J., 2017. Understanding the identity of Ibiza, Spain. J. of Travel \& Tour. Market. 34: 1033-1046. https://doi.org/10.1080/10548408.2016.1272525

Bigne, E., Ruiz, C., \& Curras-Perez, R., 2019. Destination appeal through digitalized comments. J. of Bus. Res. 101: 447-453. https://doi.org/10.1016/j.jbusres.2019.01.020

Blain, C., Levy, S.E., \& Ritchie, J.R.B., 2005. Destination branding: Insights and practices from Destination Management Organizations. J. of Travel Res. 43: 328-338. https://doi.org/10.1177/0047287505274646

Blair, T.C., Kung, S.F., Shieh, M.D., \& Chen, K.H., 2015. Competitive identity of a nation. Glob. Stud. J. 8: 13-30. https://doi.org/10.18848/18354432/CGP/v08i01/40919

Braun, V., \& Clarke, V., 2012. Thematic analysis in: H. Cooper (Ed.), APA handbook of research methods in psychology: Vol 2. -Research designs: Quantitative, qualitative, neuropsychological, and biological. American Psychological Association, Washington. pp. 57-71.

Bregoli, I., 2013. Effects of DMO coordination on destination brand identity: A mixed methods study on the city of Edinburgh. J. of Travel Res. 52: 212-224. https://doi.org/10.1177/0047287512461566

Briciu, V.A., 2013. Differences between place branding and destination branding for local brand strategy development. Bull. Transilv. Univ. of Braş, Series VII: Soc. Sci. Law, 6: 9-14.

Briciu, V.A., \& Briciu, A., 2016. A brief history of brands and the evolution of place branding. Bull. Transilv. Univ. of Braş, Series VII: Soc. Sci. Law, 9: $137-142$.

Brinklow, L., 2013. Stepping-stones to the edge: Artistic expressions of islandness in an ocean of islands. Isl. Stud. J. 8: 39-54.

Brunhes, J., 1920. Human geography: An attempt at positive classification. George C. Harrap. (Ed.) I.C. LeCompte, Trans. (Original work published 1910)

Burholt, V., Scharf, T., \& Walsh, K., 2013. Imagery and imaginary of islander identity: Older people and migration in Irish small-island communities. J. of Rural Stud. 31: 1-12.

Büscher, B. \& Fletcher, R., 2017. Destructive creation: capital accumulation and the structural violence of tourism. J. of Sustain. Tour. 25: 651667. https://doi.org/10.1080/09669582.2016.1159214

Butler, R., 2012. Islandness: It's all in the mind. Tour. Recreat. Res. 37: 173-176. https://doi.org/10.1080/02508281.2012.11081702

Cameron, C.M., \& Gatewood, J.B., 2008. Beyond sun, sand and sea: The emergent tourism programme in the Turks and Caicos Islands. J. of Herit. Tour. 3: 55-73. https://doi.org/10.1080/1743873X.2008.9701250

Campelo, A., Aitken, R., Thyne, M., \& Gnoth, J., 2014. Sense of place: the importance for destination branding. J. of Travel Res. 53: 154-166. https://doi.org/10.1177/0047287513496474

Canavan, B., 2017. Tourism stakeholder exclusion and conflict in a small island. Leis. Stud., 36: 409-425.

https://doi.org/10.1080/02614367.2016.1141975

Carr, A., Ruhanen, L. \& Whitford, M., 2016. Indigenous peoples and tourism: the challenges and opportunities for sustainable tourism. J. of Sustain. Tour. 24: 1067-1079. https://doi.org/10.1080/09669582.2016.1206112

Conkling, P., 2007. On islanders and islandness. Geogr. Rev. 97: 191-201. https://doi.org/10.1111/j.1931-0846.2007.tb00398.x 
Conway, D., \& Timms, B.F., 2010. Re-branding alternative tourism in the Caribbean: The case for 'slow tourism'. Tour. \& Hosp. Res. 10: $329-344$. https://doi.org/10.1057/thr.2010.12

Cottrell, J.R., 2017. Island community: Identity formulation via acceptance through the environment in Saaremaa, Estonia. Isl. Stud. J. 12: 169186. https://doi.org/10.24043/isj. 11

d'Hauteserre, A., 2010. Government Policies and Indigenous Tourism in New Caledonia. Asia Pac. J. of Tour. Res. 15: $285-303$.

https://doi.org/10.1080/10941665.2010.503620

Datzira-Masip, J. \& Poluzzi, A., 2014. Brand architecture management: The case of four tourist destinations in Catalonia. J. of Destin. Market. Manag. 3: 48-58. https://doi.org/10.1016/j.jdmm.2013.12.006

Daye, M., 2010. Challenges and prospects of differentiating destination brands: The case of the Dutch Caribbean Islands. J. of Travel \& Tour. Market. 27: 1-13. https://doi.org/10.1080/10548400903534725

DeChernatony, L., 1999. Brand management through narrowing the gap between brand identity and brand image. J. of Market. Manag. 15: 157179. https://doi.org/10.1362/026725799784870432

Delgado-Ballester, E., Navarro, A., \& Sicilia, M., 2012. Revitalizing brands through communication messages: The role of brand familiarity. J. of Market. 46: 31-51.

Dumontet, M., Kiprop, M., \& Loewen, C., 2019. Steps on the Path Towards Decolonization: A Reflection on Learning, Experience, and Practice in Academic Support at the University of Manitoba. Can. J. for Stud. In Discourse \& Writing/Réd., 29: 196-216.

https://doi.org/10.31468/cjsdwr.745

Dziuba, R.N., 2015. Development and formation of the place branding practice. World Sci. Discov./V Mire Nauchnykh Otkrytiy, $61: 206-215$.

Escobar, A., 2003. Mundos y Conocimientos de otro modo. El programa de investigación modernidad/colonialdad latinoamericano. Tabula Rasa. 1: 51-86.

Graham, S.C., 2020. Branding Cold-Water Islands: The use of themes related to water in logos for island tourism destinations. SHIMA, 14: 275297. https://doi.org/10.21463/shima.14.2.18

Grobert, J., Cuny, C., \& Fornerino, M., 2016. Surprise! We changed the logo. J. of Product \& Brand Manag. 25: 239-246. https://doi.org/10.1108/JPBM-06-2015-0895

Grydehøj, A., 2008. Branding from above: Generic cultural branding in Shetland and other islands. Isl. Stud. J. 3: 175-198.

Grydehøj, A., 2011. Making the most of smallness: Economic policy in microstates and sub-national island jurisdictions. Space and Polity, 15: 183-196. https://doi.org/10.1080/13562576.2011.692578

Grydehøj, A., 2018. Hearing voices: colonialism, outsider perspectives, island and Indigenous uses, and publishing ethics. Isl. Stud. J. 13 : 3-12. https://doi.org/10.24043/isj.54

Grydehøj, A., 2020. Critical approaches to island geography. AREA. 52: 2-5. https://doi.org/10.1111/area.12546

Grydehøj, A., 2021. An expanding world of islands: The emergence of Chinese Island Studies. Okinawan J. of Isl. Stud. 1: 1-9. https://doi.org/10.24043/isj.41

Hall, S., 1994. Cultural identity and diaspora in: Williams, Patrick and Laura Chrisman, Colonial discourse and post-colonial theory: a reader. pp. 227-237. Harvester Wheatsheaf, London.

Hankinson, G., 2009. Managing destination brands: Establishing a theoretical foundation. J. of Market. Manag. 25: 97-115. https://doi.org/10.1362/026725709X410052

Hay, P., 2006. A phenomenology of islands. Isl. Stud. J. 1: 19-42.

Hay, P., 2013. What the sea portends: A reconsideration of contested island tropes. Isl. Stud. J. 8: 209-232. 
Hayward, P., \& Kuwahara, S., 2014. Takarajima: A treasured island: exogeneity, folkloric identity, and local branding. J. of Mar. Isl. Cultures, 3: 20-30. https://doi.org/10.1016/j.imic.2014.03.001

Helm, C. \& Jones, R., 2010. Extending the value chain - A conceptual framework for managing the governance of co-created brand equity. J. of Brand Manag. 17: 579-589. https://doi.org/10.1057/bm.2010.19

Henthorne, T.L., George, B.P., \& Miller, M.M., 2016. Unique selling positions and destination branding: A longitudinal perspective on the Caribbean tourism in transition. Tour. 64: 261-275.

Herm, S., \& Moller, J., 2014. Brand identification by product design: The impact of evaluation mode and familiarity. Psychol. Market. 31: 10841096. https://doi.org/10.1002/mar.20755

Íslandsstofa. (n.d). Íslandsstofa: Promote Iceland. https://www.islandsstofa.is/en

Johnson, H., 2012. 'Genuine Jersey': Branding and authenticity in a small island culture. Isl. Stud. J. 7: 235-258.

Kahn, J., 2006. A brand-new approach. Foreign Policy. 2. https://foreignpolicy.com/2009/10/16/a-brand-new-approach

Katz, H., 2018. The impact of familiarity and perceived trustworthiness and influence on donations to nonprofits: An unaided recall study. J. of Nonprofit \& Pub. Sector Market. 30: 187-199. https://doi.org/10.1080/10495142.2017.1326874

Keller, K. L., Sternthal, B., \& Tybout, A., 2002. Three Questions You Need to Ask About Your Brand. Harv. Bus. Rev. Reprint RO209F, 3 - 8.

Kilduff, K., \& Nunez-Tabales, J.M., 2017. Country branding and its effect on the consumer in the global market. Cuad. Gest. 17: 83-104. https://doi.org/10.5295/cdg.150543kk

Kim, M.J., \& Lim, J.H., 2019. A comprehensive review on logo literature: Research topics, findings, and future directions. J. of Market. Manag. 35: 1291-1365. https://doi.org/10.1080/0267257X.2019.1604563

Kladou, S., Kavaratzis, M., Rigopoulou, E., \& Salonika, E., 2016. The role of brand elements in destination branding. J. of Destin. Market. Manag. 6: 426-435. https://doi.org/10.1016/j.jdmm.2016.06.011

Konecnik Ruzzier, M., \& Petek, N., 2012. The importance of diverse stakeholders in place branding: The case of "I feel Slovenia." Anatol. 23: 4960. https://doi.org/10.1080/13032917.2011.653631

Krippendorff, K., 1989. Content analysis in: E. Barnouw, G. Gerbner, W. Schramm, T.L. Worth, and L. Gross (Eds.), Int. Encycl. Comm. Oxford University Press, New York. pp. 403-407. http://repository.upenn.edu/asc_papers/226

Lange-Faria, W., \& Elliot, S., 2012. Understanding the role of social media in destination marketing. Tour. 7: 193-211.

Lee, S., Rodriguez, L., \& Sar, S., 2012. The influence of logo design on country image and willingness to visit: A study of country logos for tourism. Public Relat. Rev. 38: 584-591. https://doi.org/10.1016/j.pubrev.2012.06.006

Leseure, M., 2010. Exploitation versus exploration in island economies: A Brand diagnostic perspective. Int. of J. Entrep. \& Small Bus. 9: 463479. https://doi.org./10.1504/IJESB.2010.032405

Loureiro, S.M.C., \& Kaufmann, H.R., 2013. The impact of islands' image on tourists' satisfaction and place identity. J. of Int. Bus. \& Entrep. Dev. 7: 1-52. https://doi.org/10.1504/JIBED.2013.052131

Lugovskoy, A.V., 2015. Archetypical component in the concept of islandness. Kemer. State Univ. Bull. 1: 176-181.

Maloney, W.F. \& Montes Rojas, G.V., 2005. How elastic are sea, sand and sun? Dynamic panel estimates of the demand for tourism. Appl. Econ. Lett. 12: 277-280. https://doi.org/10.1080/1350485042000338626

Marker, M., 2000. Lummi identity and white racism: When location is a real place. International J. of Qual. Stud. Edu. 13: 401-414. https://doi.org/10.1080/095183900413359

Marti, B.E., 2005. Cruise line logo recognition. J. of Travel Tour. Market. 18: 25-31. https://doi.org/10.1300/J073v18n01_03 
McCall, G., 1994. Nissology: The study of islands. J. of Pac. Soc., 17: 1-14.

Mignolo, W.D., 2011. The darker side of Western modernity: Global futures, decolonial options. Duke University Press, Durham NC \& London http://doi.org/10.1215/9780822394501

Nadarahaj, Y., 2007. The outsider within - Commencing fieldwork in the Kuala Lumpur/Pataling Jaya Corridor, Malaysia. Int. J. of Asia-Pac. Stud. 3: 109-132.

Nadarajah, Y. \& Grydehøj, A., 2016. Island studies as a decolonial project. Isl. Stud. J. 11: 437-446.

Neilsen, N. \& Wilson, E., 2012. From invisible to Indigenous-driven: A critical typology of research in Indigenous tourism. J. of Hosp. \& Tour. Manag. 19: 67-75. https://doi.org/10.1017/jht.2012.6

Nimführ, S., \& Meloni, G.N., 2021. Decolonial thinking: A critical perspective on positionality and representations in island studies (Guest Editorial Introduction). Isl. Stud. J. 16. (forthcoming).

Nunkoo, R., \& Gursoy, D., 2012. Residents' support for tourism: An identity perspective. Ann. Of Tour. Res. 39: 243-268.

https://doi.org/10.1016/j.annals.2011.05.006

Péron, F., 2004. The contemporary lure of the island. J. of Econ. \& Soc. Geogr. 95: 326-339. https://doi.org/10.1111/j.1467-9663.2004.00311.x

Petrea, R., Petrea, D., Olau, P.E., \& Filimon, L. (2013). Place branding as efficient management tool for local government. Transilv. Rev. Admin. Sci. 9: 124-140.

Popescu, I.V., 2014. The importance of the country brand for tourism: Comparative analysis between Romania and Greece. Pract. Appl. Sci. 2: 434-441.

Rowett, P., 2016. The Lowdown on Branding for Small-Medium Size Tourism Businesses. Tourism e School. https://tourismeschool.com/blog/branding-101-tourism-businesses/

Sadler, R., Cleave, E., Arku, G., \& Gilliland, J., 2016. A comparative analysis of place branding in Michigan and Ontario. Urban Res. Practice, 9: 1636. https://doi.org/10.1080/17535069.2015.1037341

Seetanah, B., 2011. Assessing the dynamic economic impact of tourism for island economies. Ann. of Tour. Res. 38: 291-308. https://doi.org/10.1016/j.annals.2010.08.009

Selwyn, P., 1980. Smallness and islandness. World Dev. 8: 945-951. https://doi.org/10.1016/0305-750X(80)90086-8

Seraphin, H., Ambaye, A., Gowreesunkar, V., \& Bonnardel, V., 2016. A marketing research tool for destination marketing organizations' logo design. J. of Bus. Res. 69: 5022-5027. https://doi.org/10.1016/j.jbusres.2016.04.074

Sharpley, R., 2012. Island tourism or tourism on islands. Tour. \& Recreat. Res. 37: 167-172. https://doi.org/10.1080/02508281.2012.11081701

Skinner, H., 2018. Who really created the place brand? Considering the role of user generated content in creating and communicating a place identity. Comm. Soc. 31: 9-25.

Smith, L.T., 2012. Decolonizing methodologies: Research and Indigenous peoples. Zed books, London.

Sroypetch, S., 2016. The mutual gaze: Host and guest perceptions of socio-cultural impacts of backpacker tourism: A case study of the Yawawa Islands, Fiji. J. of Mar. Isl. Culture. 5. https://doi.org/10.1016/j.imic.2016.09.004

Stets, J.E., \& Biga, C.F., 2003. Bringing identity theory into environmental sociology. Sociological Theory, 21: 398-423.

https://doi.org/10.1046/j.1467-9558.2003.00196.x

Stratford, E., 2003. Editorial: Flows and boundaries: Small island discourse and challenges of sustainability, community, and local environments. Local Environ. 8: 495-499. 
Stupart, C.A. \& Shipley, R., 2012. Jamaica's tourism: Sun, sea and sand to cultural heritage. J. of Tour. Insights. 3: 4. https://doi.org/10.9707/2328-0824.1028

Sulistiyono, S.T. \& Rochwulaningsih, Y., 2013. Context for hegemony: the dynamics of inland and maritime cultures relations in the history of Java island, Indonesia. J. of Mar. Isl. Culture. 2: 115-127. https://doi.org/10.1016/j.imic.2013.10.002

Tang-Taye, J., \& Standing, C., 2016. Website translation and destination image marketing: A case study of Reunion Island. J. of Hosp. \& Tour. Res. 40: 611-633. https://doi.org/10.1177/1096348013515917

Van Duzer, C., 2006. From Odysseus to Robinson Crusoe: A Survey of Early Western Island Literature. Isl. Stud. J. 1: 143-162.

Vannini, P., \& Taggart, J., 2013. Doing islandness: A non-representational approach to an island's sense of place. Cultural Geogr., 20: $225-242$. Weale, D., 1991. Islandness. Isl. J., 8: 81-82.

Weale, D., 1992. Them times. Island Studies Press.

Weaver, D. B., 2016. Beyond convention: reimagining Indigenous tourism. Tour. Geogr. 18: 28-37.

https://doi.org/10.1080/14616688.2015.1122077

Wheeler, F., Frost, W., \& Weiler, B., 2011. Destination brand identity, values, and community: A case study from rural Victoria, Australia. J. of Travel \& Tour. Market. 28(1), 13-26.

Whitten Henry, M.J., 2020. Tasting place: Themes in food and beverage product logos from three North Atlantic island regions. J. of Gastron. Tour. 4: 157-173.

Yusof, M.F.M., Ismail, H.N., \& Omar, R.N.R., 2014. A critical analysis on evolution of branding destination in Langkawi Island. SHS Web of Conferences. https://www.shs-conferences.org/articles/shsconf/abs/2014/09/shsconf_4ictr2014_01002/shsconf_4ictr2014_01002.html 